\title{
SURGICAL MANAGEMENT OF AXIS' TRAUMATIC SPONDYLOLISTHESIS
}

\section{Hangman's fracture}

\author{
José Luiz Romeo Boullosa', Benedicto Oscar Colli², Carlos Gilberto Carlotti Jr3, \\ Koji Tanaka ${ }^{1}$, Marcius Benigno Marques dos Santos ${ }^{1}$
}

\begin{abstract}
Objective: To evaluate the results of surgical treatment using pedicle screws going through C2 pedicles for fixating the spondylolisthesis of the axis in patients who presented pseudoarthrosis after clinical treatment, or who have no condition for fixation with "halo vest", due to serious head trauma. Method: Ten patients have been operated from June 1998 to April 2002, nine suffering from traumatic spondylolisthesis of the axis caused by car accident and one horse fall. Four of those patients have undergone clinical treatment and presented signs of pseudoarthrosis, suffering intense pain at the movement of the cervical spine. Two of them presented moderate head trauma with multiple fractures of the skull. Another one was submitted to a surgical treatment for an acute extradural hematoma. Three patients presented a serious dislocation of C2 over C3. The patients were submitted to arthrodesis of the fractures with two screws, placed on the C2 pedicles, which allowed a better approximation of the fractures with the alignment of C2-C3. Two other patients required additional fixation with a plate on the lateral masses of C3. Results: Nine patients had a good post surgery evolution with satisfactory consolidation of the fractures and disappearance of the symptoms. One patient had a good evolution but still has cervical pain resulting from strain. Conclusion: The fixation of the traumatic spondylolisthesis of the axis using screws in C2 pedicles and through fractures traces is a good option for treating patients who present pseudoarthrosis after clinical treatment or who present contraindication to the "halo vest", such as skull fracture or great lacerations in the scalp.
\end{abstract}

KEY WORDS: cervical spine, traumatic spondylolisthesis of the axis (Hangman's fracture), cervical arthrodesis, raquimedullar trauma.

\section{Tratamento cirúrgico para a espondilolistese traumática do áxis (fratura do enforcado)}

RESUMO - Objetivo: Avaliar os resultados do tratamento cirúrgico usando parafuso com rosca parcial, atravessando os pedículos de C2, para a fixação da epondilolistese traumática do áxis, em pacientes que apresentam pseudoartrose após o tratamento clínico, ou que não tiveram condições de fixação com "halo vest" devido a traumatismo crânio-encefálico importante. Método: De junho de 1998 a abril de 2002, foram operados dez pacientes com espondilolistese traumática do áxis. Nove foram vítimas de acidentes automobilísticos e um sofreu queda de cavalo. Quatro pacientes tinham sido submetidos a tratamento clínico, e apresentavam sinais de pseudoartrose, com dor intensa à movimentação da coluna cervical. Dois apresentavam traumatismo crânio-encefálico moderado com múltiplas fraturas de crânio. Um foi submetido a tratamento cirúrgico de hematoma extradural agudo. Três apresentavam deslocamento importante de C2 sobre C3. Os pacientes foram submetidos a artrodese das fraturas com dois parafusos de rosca parcial colocados nos pedículos de C2, atravessando-se as fraturas, o que permitiu melhor aproximação das fraturas com alinhamento de C2-C3. Em dois pacientes foi necessária a fixação adicional com placa lateral fixa nas massas laterais de C3. Resultados: Nove pacientes tiveram boa evolução pós-operatória com consolidação satisfatória das fraturas, e desaparecimento dos sintomas. Um paciente teve boa evolução com consolidação das fraturas, mas permanece com dores cervicais aos esforços. Conclusão: A fixação da espondilolistese traumática do áxis com o uso de parafusos de rosca parcial, nos pedículos de $\mathrm{C} 2$ e através dos traços de fratura é uma boa opção para o tratamento de pacientes que apresentarem pseudoartrose após tratamento clínico, ou apresentam contraindicações para o uso do "halo vest", como fraturas da calota craniana, ou grandes lacerações de couro cabeludo.

PALAVRAS-CHAVE: coluna cervical, espondilolistese traumática do áxis, fratura de Hangman, fratura do enforcado, artrodese cervical, traumatismo raquimedular.

Hospital das Clínicas da Faculdade de Medicina de Ribeirão Preto, Neurosurgery Division, University of São Paulo, Ribeirão Preto SP, Brazil: ${ }^{2}$ Staff Physician; ${ }^{2}$ Assistent Professor Neurosurgery Division; ${ }^{3}$ Full Professor

Received 26 June 2003, received in final form 3 May 2004. Accepted 3 June 2004.

Dr. José Luiz Romeo Boullosa - Rua Visconde de Inhaúma 1650 - 14025-100 Ribeirão Preto SP - Brasil. E-mail: jlromeo@netsite.com.br 
Table 1. Patients with axis' traumatic spondylolisthesis treated with surgical fixation with pedicular screws, from June 1998 to April 2002.

\begin{tabular}{|c|c|c|c|c|c|c|c|c|c|c|c|}
\hline Patients & $\begin{array}{l}\text { Age } \\
\text { (years) }\end{array}$ & Sex & $\begin{array}{l}\text { Date of the } \\
\text { accident }\end{array}$ & $\begin{array}{l}\text { Type of } \\
\text { accident }\end{array}$ & Hospital & $\begin{array}{l}\text { Indication } \\
\text { for surgery }\end{array}$ & $\begin{array}{l}\text { Classification } \\
\text { (Effendi, et al.) }\end{array}$ & $\begin{array}{l}\text { Date of } \\
\text { surgery }\end{array}$ & Surgery performed & $\begin{array}{c}\text { Time of } \\
\text { hospitalization }\end{array}$ & $\begin{array}{l}\text { Time of } \\
\text { follow-up }\end{array}$ \\
\hline PJV & 38 & M & 19/09/97 & Vehicle & HSFco & Pseudoarthrosis & Type I & $23 / 06 / 98$ & C2 Pedicular screws & 5 days & 55 months \\
\hline VBS & 25 & M & 05/03/98 & Vehicle & HCRP & Pseudoarthrosis & Type II & 17/11/98 & C2 Pedicular screws & 6 days & 49 months \\
\hline WRS & 42 & M & 20/08/99 & Vehicle & HSFCO & $\begin{array}{l}\text { Severe } \\
\text { Head injury }\end{array}$ & Type I & $27 / 08 / 99$ & C2 Pedicular screws & 17 days & 40 months \\
\hline SDM & 21 & M & $15 / 07 / 99$ & Vehicle & HSFco & Pseudoartrosis & Type II & $02 / 03 / 00$ & C2 Pedicular screws & 4 days & 33 months \\
\hline AJNF & 31 & $\mathrm{~F}$ & $23 / 05 / 00$ & Vehicle & HSFCO & $\begin{array}{l}\text { Great dislocation } \\
\text { on } 22-\mathrm{C} 3\end{array}$ & Type II & 26/05/00 & $\begin{array}{l}\text { C2 Pedicular screws } \\
\text { with plates fixing on } \\
\text { C3 lateral mass }\end{array}$ & 7 days & 31 months \\
\hline OAS & 40 & $M$ & $12 / 01 / 01$ & Vehicle & HCRP & $\begin{array}{c}\text { Severe } \\
\text { head injury }\end{array}$ & Type II & $22 / 01 / 01$ & C2 Pedicular screws & 19 days & 23 months \\
\hline $\mathrm{CCP}$ & 52 & $\mathrm{~F}$ & $11 / 02 / 00$ & Vehicle & HSFCO & Pseudoarthrosis & Type II & $30 / 08 / 01$ & C2 Pedicular screws & 5 days & 16 months \\
\hline JAM & 25 & M & 01/10/01 & Vehicle & HCRP & $\begin{array}{c}\text { Severe head } \\
\text { injury (Extradural } \\
\text { hematoma) }\end{array}$ & Type II & 09/10/01 & C2 Pedicular screws & 7 days & 14 months \\
\hline JMS & 32 & M & $26 / 03 / 02$ & Vehicle & HCRP & $\begin{array}{l}\text { Great dislocation } \\
\text { on } 22-\mathrm{C} 3\end{array}$ & Type II & $29 / 03 / 02$ & $\begin{array}{l}\text { C2 Pedicular screws } \\
\text { with plates fixing } \\
\text { on C3 lateral mass }\end{array}$ & 7 days & 9 months \\
\hline JCPS & 51 & M & $23 / 04 / 02$ & Horse fall & HSFCO & $\begin{array}{l}\text { Great dislocation } \\
\text { on } 22-\mathrm{C} 3\end{array}$ & Type II & $27 / 04 / 02$ & C2 Pedicular screws & 5 days & 8 months \\
\hline
\end{tabular}

"Hangman's fracture" and Axis Traumatic Spondylolisthesis(ATS) are terms which have been used to describe a specific fracture group, which involve the posterior C2 elements'. Wood-Jones, in 1913, described the $\mathrm{C} 2$ vertebrae fracture produced by the hanging in an article entitled "The ideal Lesion Produced by Hanging" observing that the lesion was produced by the violent cervical traction with the abrupt stretching of the head backwards, causing the C2 pedicle fractures ${ }^{2}$. In 1964, Garber ${ }^{3}$ described C2 pedicle fractures with the forward dislocation of the $\mathrm{C} 2$ body in patients victims of motor vehicle accidents, what was denominated "Axis' Traumatic Spondylolisthesis". In 1965, Schneider et al. ${ }^{4}$ described a new series of patients with the same fractures described by Wood-Jones and by Garber, denominating it "Hangman's Fracture".

The ATS was referred to as an uncommon and predominantly stable lesion, rarely accompanied by neurological deficit, for which the recommended treatment was the cervical traction and rigid immobilization $^{3,4}$. Studies indicated that these kinds of traumatic lesions are a frequent consequence of motor vehicle accidents and falls, corresponding from 7 to $20 \%$ of cervical fractures, and from 20 to $23 \%$ of (C2) axis' fractures ${ }^{5,6}$.

A simple cervical spine lateral X-ray can diagnose the majority of the cases. Computed axial tomography of the cervical column with bone window can show more details of the lesion ${ }^{7,8}$. Even though some authors suggest surgical treatment to all Hangman's Fracture cases ${ }^{9}$. The majority of them agree that in most cases the conservative treatment is the most indicated, either with use of semi-rigid collars in cases of a small degree of dislocation, or rigid immobilizations like the "halo-vest", in cases of great luxations ${ }^{5,6,10-12}$.

Nevertheless, in some cases the conservative treatment may not produce a satisfactory fracture consolidation, resulting in pseudoarthosis, which can present pain not only during head movement but also during rest, or produce great luxations endangering the cervical canal or medullar compression, 10,12-21. Another problem is the sprains of C2 over $\mathrm{C} 3$, for which a conservative treatment with good alignment cannot be obtained. In addition, patients with ATS needing neurosurgical procedures or showing skull fractures or still acute scalp lesion usually cannot be submitted to treatment with external immobilization. In these cases, surgical treatment can be a good option. Various surgical techniques were suggested, starting from the occipito-cervical fixing by posterior approach with the use of metal implants and bone graft, up to the C2-C3 anterior fixied by trans-oral aproach ${ }^{13-17}$. Laconte et al. ${ }^{21}$ describe the $\mathrm{C} 2$ direct pedicles fixing technique for the ATS. It is a technique which preserves the cervical column mobility and that can offer good results in terms of alignment and effective fixing with a low level of pseudoarthrosis ${ }^{14,19,22}$. 
The objective of the present study is to evaluate the results of the surgical treatment with partially threaded screws passing through the $\mathrm{C} 2$ pedicles, for the fixing of the Axis' Traumatic Spondylolisthesis.

\section{METHOD}

\section{Casuistcs}

From June 1998 to April 2002, ten patients with ATS have been operated. Four patients were admitted and operated on at São Paulo University Medical School "Hospital das Clínicas" Emergency Unit from Ribeirão Preto, and six patients were seen and operated at São Francisco's Hospital (in the city of Ribeirão Preto).

The age of the patients varied from 25 to 52 , with an average age of 35.7 years. Eight patients were males and two were females.

Nine patients were motor vehicle accident victims and one was a victim of a horse fall. Four patients had been submitted previously to conservative treatment, and showed signs of pseudoarthrosis, with intense pain in the cervical spine. Three patients showed head injury, two of them with multiple cranial fractures and the third one was submitted to surgical treatment for acute extradural hematoma. Three showed important C2 over

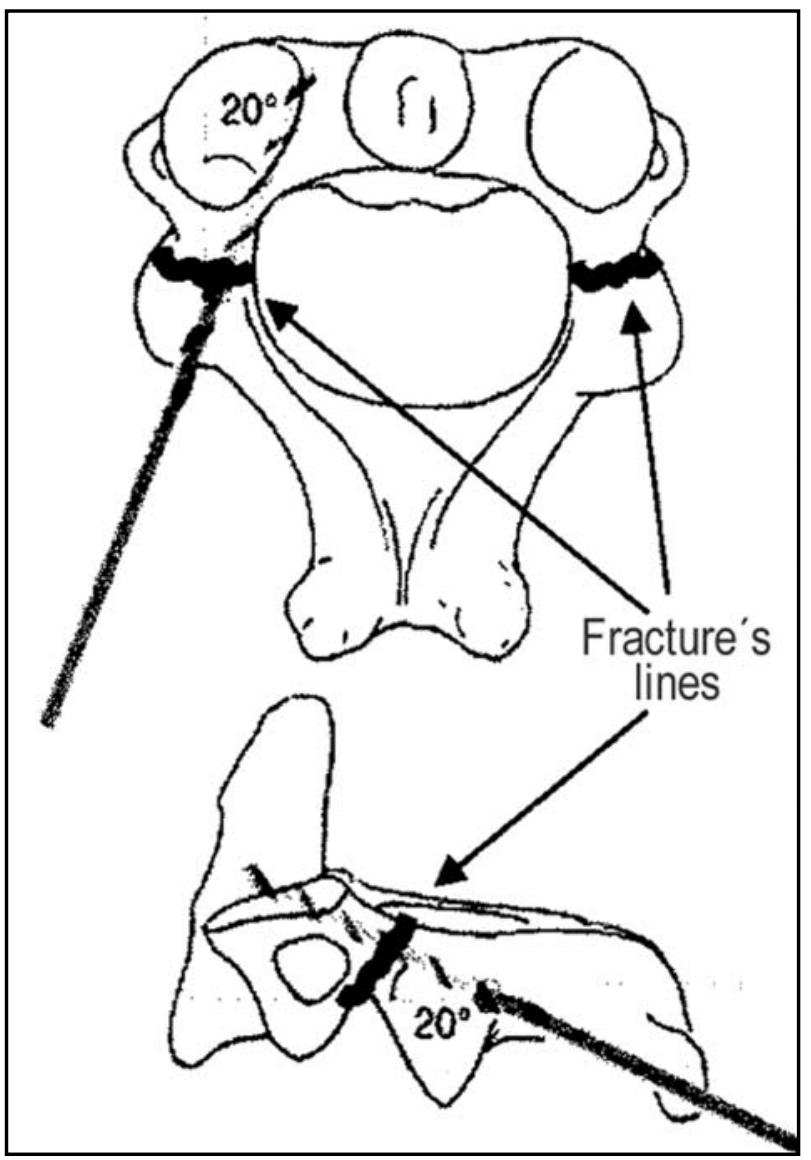

Fig 1. Scheme showing the trajectories and angulations of the drill, avoiding neurovascular lesions.
C3 dislocation which was not reduced satisfactorily with the conservative treatment.

None of the patients showed neurological deficit. The details of each case are shown on Table 1.

\section{Procedure}

All of the patients were submitted to simple X-rays and computed tomography of the cervical column, confirming the $\mathrm{C} 2$ pedicle fracture diagnosis, without compromising the vertebral body from the same vertebrae. In the cases of pseudoarthrosis after the conservative treatment, dynamic x-rays of the cervical column (bending and stretching) were also performed aiming to confirm a flaw in the fracture's consolidation.

All of the patients were operated by the head author.

Surgical technique - All of the patients were submitted to $C 2$ pedicle artrodesis, a screw fixed on each pedicle crossing the fracture lines, with the technique described by Laconte et al. ${ }^{21}$. The patient is positioned in the ventral decubitus with the face resting on a cranial support iron tool or with the head fixed by a Mayfield type support, keeping the best possible C2-C3 alignment. Continous cervical radioscopy on lateral view is obtained during the surgery to see in specially the C2's pedicles and body. The incision is made on the median line with the extension of approximately $8 \mathrm{~cm}$, centered on $\mathrm{C} 2$, on the cervical spine posterior face. The C2 articular masses are exposed and a electric scalpel is used to detach the para-vertebral musculature. Two holes are made with a drill connected to a light drilling machine, or to a high-speed motor, one in each articular mass, in its central part. The drilling is then proceeded towards the $\mathrm{C} 2$ vertebral body keeping an inclination of approximately 20 degrees in the axial plane and approximately about 20 degrees in the sagittal plane (Fig 1). This last

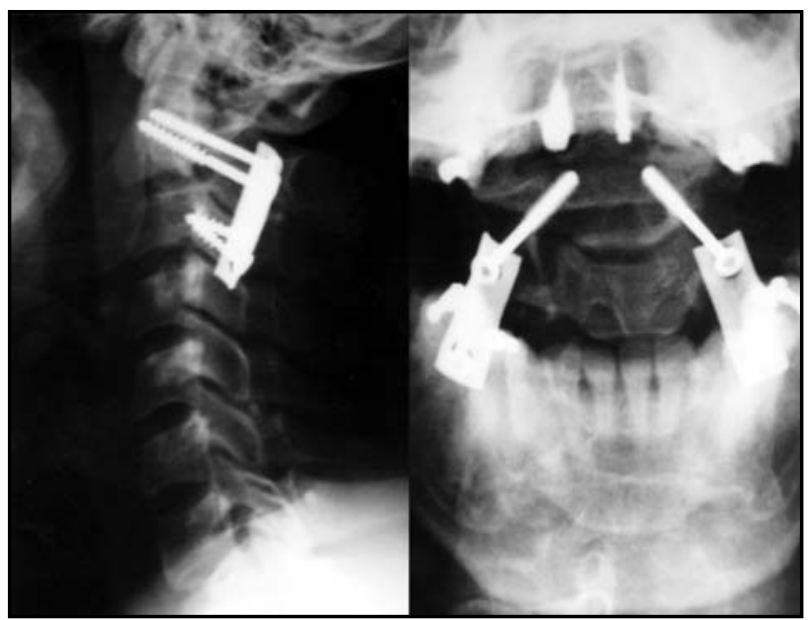

Fig 2. Lateral cervical radiography (A) and frontal radiography (B) pos-surgical showing a Axis Traumatic Spondylolisthesis treated with the passage of 2 screws in the $C 2$ pedicles, and 2 screws on the lateral masses of C3, and 2 plates fixing C2-C3, with a good reduction of the deformity. 


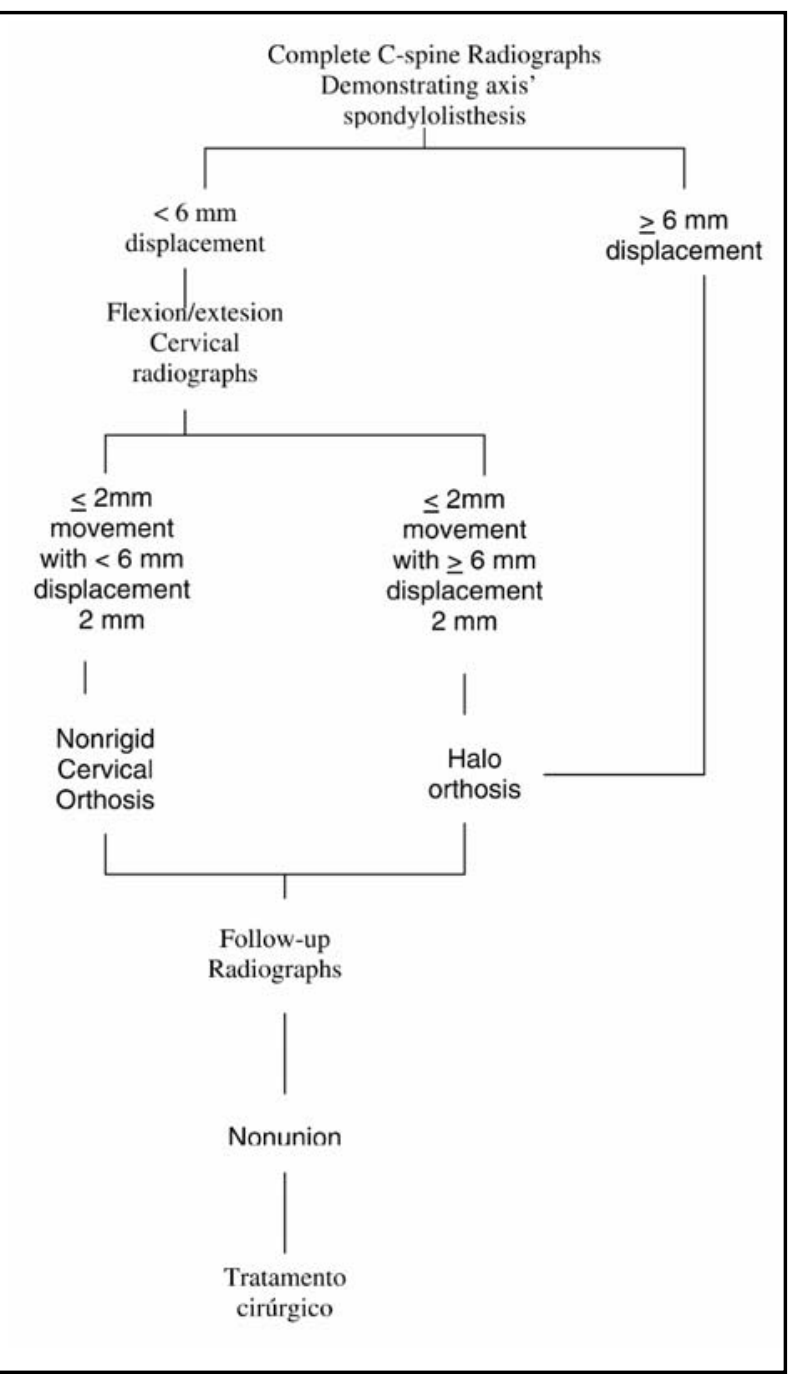

Fig 3. Fluxogram showing the treatment algorithm for the management of axis' traumatic spondylolisthesis suggested by Coric et al. (1996)'.

inclination has to be followed by the continous X-rays, in order to keep the drill strictly within the $\mathrm{C} 2$ pedicles. In each of those two trajectories, the "guiding wires" are inserted. These wires will guide the two $3.5 \mathrm{~mm}$ diameter canulated screws, with the thread only at the end (called partial thread screws). The correction and the fracture fixing are better obtained when the 2 screws are fixed simultaneously, pulling in an equal manner the $\mathrm{C} 2$ vertebral body towards the fractured pedicles. Cases that the sprain reduction becomes more difficult, a lateral mass plate can be added connecting the $\mathrm{C} 2$ pedicle screws to 2 lateral mass ones on the $\mathrm{C} 3$ as described by Roy-Camille et al. ${ }^{23}$. On these series, in only 2 cases we needed to add the $\mathrm{C} 3$ fixing for a better sprain reduction (Fig 2).

All the patients used a semi-rigid cervical collar (Philadelphia collar) for a period of 30 days.

Follow up - The patients were reevaluated clinically $30,60,90$ and 180 days after the surgery. Since the evolution was satisfactory, the subsequent follow-ups were set up on a yearly basis. On the follow-ups, physical and neurological exams, the pain complaints or paresthesia as well as the cervical column mobility were also evaluated. The patients were also asked about their satisfaction level with the surgery.

Radiological control was done on the second postoperatory day as well as on the scheduled follow-ups.

The clinical follow-up period varied from 8 to 55 months.

\section{RESULTS}

Nine patients had good post-operatory improvement with satisfactory fracture consolidation, and the total disappearance of the symptoms.

There was no intra or post-operatory complication, except with a patient who showed lung infection on the $3^{\text {rd }}$ post-operatory day, which decreased in 7 days of antibiotic-therapy treatment.

The hospitalization period varied from 4 to 19 days.

Only one patient indicated frequent cervical pain, mainly when intense physical effort was done, what improved with rest and the use of nonsteroid analgesics.

On the check-up X-rays, all of the patients showed satisfactory consolidation signs after six months of surgery.

All of the patients mentioned being satisfied with the surgery, and declared that if necessary, would submit themselves again to the same procedure.

\section{DISCUSSION}

Since Schneider et al. correlated the occurrence of the $\mathrm{C} 2$ pedicle fractures with motor vehicle accidents and falls, and used the term "Hangman's Fracture" due to the similarities with the fractures that occurred on the cervical column of hanged individuals ${ }^{11,16,23}$. Today, 50 to $80 \%$ of the axis' traumatic lesions are resulting from motor vehicle accidents, and 10 to $40 \%$ are due to great falls $4,6,24,25$. The majority of the authors consider this fracture to be generally stable, with good prognosis and generally conservative treatment $t^{4,5,18,25}$. They are rarely accompanied by neurological lesions, once the pedicles fractures promote a widening of the vertebral canal in that area ${ }^{4,5}$. The ATS is also associated with a high incidence of head injuries and other cervical traumas $(79 \%)^{18,26}$. The rare important C2 over C3 sprain cases occur by the ligament rupture of the $\mathrm{C} 2-\mathrm{C} 3$ disc, and spinal cord compression can occur ${ }^{12,16-18}$. On these cases, the fracture would become unstable and a surgical treatment indication on the acute lesion phase can be discussed $^{11,18,24,25}$. 
The stable and unstable classification of these lesions can help with indication of a surgical or conservative treatment ${ }^{1}$. Nowadays, the most widely used classification for ATS is from Effendi et at ${ }^{24}$. and Levine \& Edwards ${ }^{25}$, which modified Effendi et al classification. Both classifications take into account fractures' action mechanism and the lesion seriousness, and can be of help in choosing the best treatment for each case. Type III fractures are the rarest. Levine \& Edwards subdivided the Type III in three variations: 1) bipedicular fractures with bilateral dislocation of the articular facets. 2) unilateral facet of the articular facets or combined dislocations with a neural arch contralateral fracture. 3) bilateral dislocation of the articulate facets associated with the $\mathrm{C} 2$ bilaminal fractues. On both classifications, the Type I lesions are classified as stable and Type II and III as unstable 1,24,25.

The majority of the authors suggest that the first ATS treatment is rigid immobilization (halo-vest, i.e. $)^{5,6,10-12,16,19,27}$. It is a kind of immobilization that produces a high level of fracture consolidation, with a pseudoarthrosis level of about $5 \%{ }^{15}$. Choric et al. ${ }^{1}$ suggest a fluxogram for the ATS' treatment (Fig 3). In this work, Coric et al. come to an agreement that the majority of the patients with the ATS diagnosis can be treated with non-rigid immobilizations (Philadelphia collar i.e.)' ${ }^{1}$. Grady et al. also consider that the major part of these patients can be treated with the use of the Philadelphia collar ${ }^{28}$.

Several surgical techniques have been described for the ATS fixing. Some authors suggest the anterior approach, with a bony graft insertion in the C2C3 space, and segment fixing with anterior plates ${ }^{29}$.

Wilson et al. ${ }^{21}$ described the $\mathrm{C} 2-\mathrm{C} 3$ disc transoral approach, and the $\mathrm{C} 2-\mathrm{C} 3$ fixing with bony graft and a titanium anterior cervical plate. The result was satisfactory, but it deals with a complex technical surgery. The access way demands great surgical knowledge with the local anatomy, and it is followed by a relatively high level of morbidity. For us, these previous approaches would only be indicated in cases of complex axis' fractures, involving the $\mathrm{C} 2$ body.

The majority of the authors prefer the posterior fixation, such as the passing of the metal wires, tying the $\mathrm{C} 1$ to $\mathrm{C} 3$ spin apophysis, hind head fixation to C3, using metallic implants (Luque's rectangle), or pedicular screws in C3 lateral masses, all using bone graft to consolidate the fracture ${ }^{13,16}$.
The direct C2 pedicle fixation to the ATS described by Laconte et al. ${ }^{19}$ preserves the cervical column mobility and can obtain good results for alignment and effective fixation with low pseudoarthrosis level $^{14,19,22}$. The biggest risk described in the literature, for this procedure is the occurrence of neurovascular lesions (vertebral artery lesion or penetration into the vertebral canal) $)^{1,13,14,23}$.

Ebraheim et al. ${ }^{17}$ showed that the pedicular screws passage through to the $\mathrm{C} 2$ medial and superior portion of the pedicles is a safe procedure. To attain more safety during this procedure, Taller et al. suggest the pedicular screw passage guided by computed axial tomography ${ }^{30}$. Roy-Camille et al. ${ }^{23}$ described the C2-C3 fixation in the cases of the ATS using two lateral mass plates, fixed with a passage of two screws in the $\mathrm{C} 2$ pedicles and two screws in the C3 lateral masses.

In our series, it is to be noted that nine of the patients had motor vehicle accidents, and 1 patient fell from a horse, which coincides with the literature, since the majority of the patients with ATS are victims of these accidents or falls.

In our opinion, the conservative treatment is the initial management in the most of the ATS cases, as the majority of the cited authors suggest. We believe that the use of $\mathrm{C} 2$ pedicular screws, isolated or in connection with lateral mass plaques, is a good approach for the resolution of specific cases, such pseudoarthrosis after the conservative treatment with great fracture instability and for patients with head injuries that do not allow the use of the halo-vest.

In this series, the post-operatory improvement showed to be satisfactory, with only one patient complaining of pain during the clinical evolution. The pain appeared when he executed activities, which demanded some kind of major physical effort. This patient had a great sprain and was submitted to arthrodesis in the acute phase with the use of plates, C3 lateral mass screws and hipbone crest graft. The post-operatory $\mathrm{X}$-rays showed the fracture consolidation and the bone graft incorporation.

During the surgical procedures, there wasnot any vascular or neural structure lesions. Even with the risk being always present and being inherent to the procedure, the correct angular position during the drill and the screws passage, the careful planning of the procedure in the pre-operatory phase and the visualization of the pedicles with the 
use of continuous radioscopy on lateral view prevented this kind of lesion.

In patients with pseudoarthrosis (four), the interval between the accident and the surgery was from 8 to 18 months (with an average of 10.7 months). In spite of the relatively long period, the four cases had good evolution with their fracture consolidation and complete remission of their preoperational symptoms.

The hospitalization period was relatively short ( 4 to 19 days with an average of 8.2 days) and the need the need for longer hospitalization was due to the head trauma and not because of the surgical procedure. The fixing of the fractures in patients with severe head trauma facilitated the work of the nursing and physical therapy staff, allowing early mobility of the patients, their removal from the bed, reducing the morbidity of the lesions.

\section{CONCLUSION}

The fixing of Axis' Traumatic Spondylolisthesis by means of screws with partial threads, in the $\mathrm{C} 2$ pedicles through the fracture line is a good option for patient that presents pseudoarthrosis after clinical treatment or presents contra-indication for the use of "halo-vest", like skull fractures or greater scalp lacerations.

The procedure offers a good initial stability and produces a high rate of fracture consolidation.

In cases where the instability is higher or with difficulty in decreasing the luxation, the association with plates and screws for lateral mass in C3 gives a more effective fixation.

\section{REFERENCES}

1. Coric D, Wilson JA, Kelly DL Jr.Treatment of traumatic spondylolisthesis of the axis with nonrigid immobilization: a review of 64 cases. J Neurosurg 1996;85:550-554.

2. Wood-Jones F. The ideal lesion produced by judicial hanging. Lancet 1913;1:53-54.

3. Garber JN. Abnormalities of the atlas and axis vertebrae - congenital and traumatic. J Bone Joint Surg 1964;46:1782-1791.

4. Schneider RC, Livingston KE, Cave AJE. "Hangman's frature" of the cervical spine. J Neurosurg 1965;22:141-154

5. Hadley MN, Browner C, Sonntag VK. Axis fractures: a comprehensive review of management and treatment in 107 cases. Neurosurgery 1985;17:281-290.
6. Hadley MN, Dickman CA, Browner CM. Acute axis fractures a review of 229 cases. J Neurosurg 1989;71:642-647.

7. Baumgarten M, Mouradian W, Boger D, Watkins R. Computed axial tomography in C1-C2 trauma. Spine 1985;10:187-192.

8. Clark CR, Igram CM, el-Khoury GY, Ehara S. Radiographic evaluation of cervical spine injuries. Spine 1988;13:742-747.

9. Cornish B. L. Traumatic spondylolisthesis of the axis. J Bone Joint Surg 1968;50:31-43.

10. Cooper PR, Maravilla KR, Sklar FH, Moody SF, Clark WK. Halo immobilization of cervical spine fractures: indications and results. J Neurosurg 1979;50:603-610.

11. Sonntag VKH, Dickman CA. Treatment of upper cervical spine injuries. In Rea GL, Miller CA (eds). Spinal trauma: current evaluation and management Parkridge: American Association of Neurological Surgeons, 1993:25-74.

12. Sonntag VKH, Hadley MN. Nonoperative management of cervical spine injuries. Clin Neurosurg 1988;34:630-649.

13. Abumi K, Kaneda K.Pedicle screw fixation for nontraumatic lesions of the cervical spine. Spine. 1997;22:1853-63.

14. Borne GM, Bedou GL, Pinaudeau M. Treatment of pedicular fractures of de axis: a clinical study and screw fixation technique. J Neurosurg 1984;60:88-93.

15. Bridwell KH. Treatment of a markedly displaced hangman's fracture with a luque rectangle and a posterior fusion in a 71-year-old man: case report. Spine 1986;11:49-52.

16. Bucholz RD, Cheung KC. Halo vest versus spinal fusion for cervical injury: evidence from an outcome study. J Neurosurg 1989;70:884-892.

17. Ebrahein N, Rollins JR Jr, Xu R, Jackson WT. Anatomic consideration of C2 pedicle screw placement. Spine 1996;21:691-695.

18. Francis WR, Fielding JW, Hawkins RJ, Pepin J, Hensinger R. Traumatic spondylolisthesis of the axis. J Bone Joint Surg 1981;63:313-318.

19. Greene KA, Dickman CA, Marciano FF, Drabier JB, Hadley MN, Sonntag VK. Acute axis fractures. Analysis of management and outcome in 340 consecutive cases. Spine 1997;22:1843-1852.

20. Verheggen R, Jansen J. Hangman's fracture: arguments in favor of surgical therapy for type II and III according to Edwards and Levine. Surg Neurol 1998:49:253-261.

21. Wilson AJ, Marshall RW, Ewart M. Transoral fusion with internal fixation in a displaced Hangman's fracture. Spine 1999;24:295-298.

22. Leconte $P$. Fracture et luxation des deux premières vertebras cervicales. In Judet R (ed). Luxation congenitale de la hanche. Fractures du coude-pied rachis cervical. Actualités de chirurgie orthopédique de l'Höpital Raymond-Poincaré, Vol 3. Paris: Masson, 1964:147-166.

23. Roy-Camille R, Saillant G, Mazel C. Internal fixation of the unstable cervical spine by a posterior ostosynthesis with plats and screws. In The Cervical Spine Research Society (ed). The cervical spine, $2^{\text {nd }}$ Ed. Philadelphia: Lippincott, 1989:390-403.

24. Effendi B, Roy D, Cornish B, Daussault RG, Laurin CA. Fractures of the ring of the axis: a classification based on the analysis of 131 cases. J Bone Joint Surg 1981;63:319-327.

25. Levine AM, Edwards CC. The management of traumatic spondylolisthesis of the axis. J Bone Joint Surg 1985;67:217-226.

26. Fielding JW, Francis WR Jr, Hawkins RJ, Pepin J, Hensinger R. Traumatic spondylolisthesis of the axis. Clin Orthop 1989;239:47-52.

27. Chan RC, Schweigel JF, Thompson GB. Halo-thoracic brace immobilization in 188 patients with acute cervical spine injuries. J Neurosurg 1983;58:508-515.

28. Grady MS, Howard MA, Jane A, et al. Use of the Philadelphia collar as an alternative to the halo vest in patients with C2-C3 fractures. Neurosurgery 1986;17:151-156.

29. Agrillo U, Mastronardi L, Prezioso A, Puzzilli F. Hangman's fracture. Spine 1999;24:2412.

30. Taller S, Suchomel P, Lukas R, Beran J. CT-guided internal fixation of a Hangman's fracture. Eur Spine J 2000;9:393-397. 